\title{
PENGALAMAN PELANGGAN, REFERENCE GROUP, PERSEPSI HARGA DALAM KEPUTUSAN PEMBELIAN PRODUK ETNIK FASHION
}

\author{
Alfi Fajria Wibowo*, Jeni Wulandari, Prasetya Nugeraha \\ Jurusan Ilmu Administrasi Bisnis, Fakultas Ilmu Sosial dan Politik, Universitas Lampung \\ *alfiwibowofajria@gmail.com
}

\begin{abstract}
This study aimed to determine the effect of customer experience, reference group and price perception on consumer purchasing decisions at fashion ethnic product. The population in this study was the consumers of Juragan Kain Boutique. The data were obtained from questionnaires that were filled in online using a likert scale; the sampling technique used purposive sampling with total sample of 100 respondents of Juragan Kain Boutique consumers. The data analysis in this study used descriptive data analysis and multiple linear regression analysis. The results of this study indicated that customer experience; reference group and price perception partially and simultaneously had positive and significant effect on purchasing decision. In this study, price suitability with product quality was the dominant factor in price perception, because it determined the purchasing decision of the Juragan Kain boutique as an ethnic fashion product.
\end{abstract}

Keywords: Customer Experience, Reference Group, Price Perception, Purchasing Decision

\begin{abstract}
ABSTRAK
Penelitian ini bertujuan untuk mengetahui adakah pengaruh pengalaman pelanggan, reference group dan persepsi harga terhadap keputusan pembelian konsumen produk etnik fashion. Populasi dalam penelitian ini adalah konsumen Butik Juragan Kain. Data tersebut diperoleh dari kuisioner yang diisi secara online dengan menggunakan skala likert, teknik pengambilan sampel menggunakan purposive sampling, dengan jumlah sampel sebanyak 100 responden konsumen Butik Juragan Kain. Analisis data dalam penelitian ini menggunakan analisis data deskriptif dan analisis regresi linier berganda. Hasil penelitian ini menunjukkan bahwa pengalaman pelanggan, reference group dan persepsi harga, secara parsial dan simultan berpengaruh positif dan signifikan terhadap keputusan pembelian. Pada penelitian ini kesesuaian harga dengan kualitas produk menjadi faktor dominan dari persepsi harga, karena menentukan keputusan pembelian Butik Juragan Kain sebagai produk ethnic fashion.
\end{abstract}

Kata kunci: likuiditas, profitabilitas, ukuran perusahaan, corporate social responsibility disclosure 


\section{PENDAHULUAN}

Dunia fashion di Indonesia bisa dikatakan berkembang sangat pesat. Hal ini didukung dari berbagai sisi, baik desainer lokal yang semakin potensial dan berdistribusi penuh dalam pengelolaan budaya Indonesia, yang kemudian dikembangkan menjadi sebuah pakaian atau trend fashion, dan juga dapat dilihat dari tingkat perekonomian yang baik, yaitu perkembangan industri tekstil dan pakaian jadi di Indonesia yang tinggi dari tahun 2016 sampai 2018.

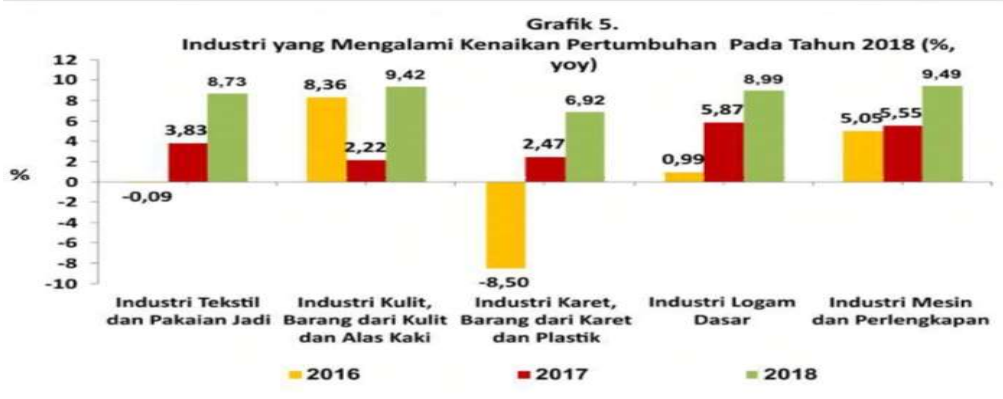

Sumber :kemenperin.go.id, (2018)

Gambar 1. Industri yang Mengalami Kenaikan Pertumbuhan

Berdasarkan data diatas, pada tahun 2016, industri tekstil dan pakaian jadi mengalami pertumbuhan sebesar 0,09\%, dan pada tahun 2017 industri tekstil dan pakaian jadi mengalami peningkatan sebesar 3,83\%. Lalu, pada tahun 2018 mengalami pertumbuhan yang tinggi yaitu sebesar 8,73\%. Pada tahun 2018 industri tekstil mengalami kenaikan sebesar 4,9\% lebih tinggi dari pertumbuhan sebesar 3,74\% pada tahun 2017 (Kemenperin.go.id, 2018).

Berkembang pesatnya pertumbuhan industri tekstil diikuti oleh perkembangan trend fashion di Indonesia pada tahun 1990. Didukung pula dengan berkembangnya dunia seni seperti majalah, perfilman, musik, dan sebagainya. Pada tahun 2000, dua desainer Indonesia yaitu Edward Hutabarat dan Anne Avantie mendedikasikan kreasi mereka dengan mendesain pakaian tradisional "blus kebaya” dengan sentuhan modern. Sehingga, membuat busana tradisional Indonesia terlahir kembali dan dicintai oleh kalangan muda.

Melihat hal tersebut, beberapa desainer Indonesia mulai merancang sebuah busana dengan mengusung tema ethnic. Ethnic merupakan gaya berpakaian yang menggunakan kain khas daerah sebagai bahan utama yang desainnya diadopsi dari luar negeri, seperti kain tenun dengan model jumputan yang siap pakai (ready to wear). Sehingga terlihat lebih casual dan classy, dengan tujuan untuk memberi kenyamanan pada saat menggunakan pakaian tradisional, serta melestarikan dan menjaga warisan budaya Indonesia.

Butik Juragan Kain merupakan salah satu dari banyaknya industri kreatif yang bergerak di bidang ethnic fashion di Bandar Lampung. Butik Juragan Kain memiliki jumlah followers (pengikut) di instagram terbanyak, yaitu 99.300 pengikut per Maret 2020. Juragan Kain tak hanya menjual pakaian, tetapi juga menjual coat, sepatu, kain maupun aksesoris khas daerah. Banyak ragam kain batik dan tenun khas daerah yang dapat ditemui di Juragan Kain, diantaranya batik Cirebon motif piring selampad yang didesain menjadi setelan lilit atasan dan bawahan, kain viscose dengan desain atau motif jumputan, kain katun paris dengan motif batik kombinasi dan sebagainya.

Selain menawarkan produk fashion (pakaian) yang berkualitas, Butik Juragan Kain juga memberikan pengalaman positif kepada konsumen. Saat memasuki butik, konsumen 
akan disuguhkan desain interior yang menarik dan unik, serta kenyamanan dalam memilih dan mencoba baju, dan pelayanan yang responsif, dimana karyawan Butik Juragan Kain akan membantu konsumen yang kesulitan dalam memakai pakaian tersebut (Wawancara dengan Odilia Fristy, 29 th, Pegawai Negeri Sipil (PNS), 20/11/2019, 14.02 WIB). Pengalaman pelanggan yang diberikan Butik Juragan Kain, menyentuh faktor psikologis pembeli, dan mempengaruhi keputusan pembelian mereka.

Fenomena tersebut menarik untuk diteliti, karena sebagai sebuah butik bertema ethnic, dengan harga yang relatif mahal, Butik Juragan Kain tetap digemari banyak orang. Pengalaman pelanggan, reference group, dan persepsi harga dapat menjadi faktor yang mempengaruhi keputusan pembelian konsumen Butik Juragan Kain, sebagaimana terdapat dalam beberapa penelitian terdahulu yang menjelaskan keterkaitan ketiga variabel tersebut terhadap keputusan pembelian (Sidabutar et al., 2016:96; Apriyandani et al., 2017:187; Jamaludin et al., 2015:6).

Menurut Schmidt (1999), pengalaman pelanggan merupakan pendekatan pemasaran yang melibatkan emosi serta perasaan konsumen dengan menciptakan pengalamanpengalaman positif yang tidak terlupakan, sehingga konsumen akan terus-menerus mengkonsumsi produk tersebut. Indikator pengalaman pelanggan meliputi: sense, feel, think, act dan relate. Terdapat beberapa penelitian terdahulu yang menunjukkan pengaruh pengalaman pelanggan dengan keputusan pembelian, sebagaimana penelitian yang telah dilakukan oleh Sandi (2017) bahwa pengalaman pelanggan berpengaruh positif dan signifikan terhadap keputusan pembelian. Berdasarkan hasil penelitian tersebut, maka dapat disusun hipotesis pertama, yaitu

H1: Pengalaman pelanggan berpengaruh signifikan terhadap keputusan pembelian produk ethnic fashion di Butik Juragan Kain

Sementara itu, reference group atau kelompok acuan adalah kelompok yang dianggap sebagai dasar referensi seseorang dalam menentukan keputusan pembelian dan juga dianggap perspektif atau nilai-nilai yang digunakan individual sebagai dasar untuk perilakunya saat ini (Hawkin, 2010). Kelompok referensi dapat mencakup keluarga, kelompok pertemanan, kelompok sosial formal, kelompok belanja, kelompok kerja dan kelompok aksi konsumen. Terdapat beberapa penelitian terdahulu yang menunjukkan pengaruh suasana toko dengan keputusan pembelian, sebagaimana penelitian yang telah dilakukan oleh Apriyandani, et al. (2017), bahwa kelompok referensi berpengaruh positif terhadap keputusan pembelian. Berdasarkan hasil penelitian tersebut, maka dapat disusun hipotesis kedua, yaitu:

H2: Reference group berpengaruh signifikan terhadap keputusan pembelian produk ethnic fashion di Butik Juragan Kain

Sedangkan persepsi harga adalah cara konsumen memandang atau mempersepsikan tinggi atau rendah dan wajarnya suatu harga pada produk dan jasa mempunya pengaruh kuat terhadap minat beli dan keputusan pembelian (Schiffman \& Kanuk, 2008:160). Indikator persepsi harga meliputi keterjangkauan harga, daya saing harga, kepatuhan dengan kualitas produk, kesesuaian harga dengan manfaat produk. Terdapat beberapa penelitian terdahulu yang menunjukkan pengaruh persepsi harga dengan keputusan pembelian, sebagaimana penelitian yang telah dilakukan oleh Jamaludin, et al(2015), Suleman, et.al (2018) bahwa persepsi harga berpengaruh positif terhadap keputusan pembelian. Berdasarkan hasil penelitian tersebut, maka dapat disusun hipotesis ketiga, 
yaitu:

H3: Persepsi Harga berpengaruh signifikan terhadap keputusan pembelian produk ethnic fashion di Butik Juragan Kain

Ketiga variabel tersebut diduga berpengaruh terhadap keputusan pembelian. Menurut Tjiptono (2010:21), keputusan pembelian adalah sebuah proses dimana konsumen mengenal masalahnya, lalu mencari informasi mengenai produk atau merek tertentu, dan mengevaluasi seberapa baik dari masing-masing alternatif tersebut dapat memecahkan masalahnya, yang kemudian mengarah kepada keputusan pembelian. Terdapat keterkaitan variabel pengalaman pelanggan, reference group,dan persepsi harga secara simultan terhadap keputusan pembelian (Sidabutar et al., 2016:96; Apriyandani et al., 2017:187; Jamaludin et al., 2015:6). Berdasarkan haL tersebut maka dapat disusun hipotesis ke empat, yaitu

H4: Pengalaman Pelanggan, Reference Group, dan Persepsi Harga secara simultan berpengaruh signifikan terhadap keputusan pembelian produk ethnic fashion di Butik Juragan Kain

\section{METODE PENELITIAN}

Penelitian ini merupakan jenis penelitian explanatory research dengan pendekatan kuantitatif. Populasi dalam penelitian ini adalah konsumen Butik Juragan Kain pada periode bulan Juli 2020. Sampel dalam penelitian ini sebanyak 100 responden, yang didapat dengan menggunakan rumus Slovin dengan tingkat toleransi kesalahan (margin of eror) sebesar $10 \%$. Penarikan sampel dalam penelitian ini menggunakan nonprobability sampling dengan teknik sampling yang digunakan yaitu purposive sampling, teknik pengambilan sampel dengan didasarkan ciri-ciri khusus yang sesuai dengan tujuan penelitian, sehingga diharapkan dapat menjawab permasalahan penelitian (Sugiyono, 2017). Penyebaran kuisioner penelitian ini dilakukan secara online melalui google form dan media yang digunakan melalui aplikasi instagram.

Adapun analisis data dilakukan dalam beberapa tahapan, yakni analisis deskriptif yang meliputi karakteristik responden dan distribusi jawaban responden, lalu uji asumsi klasik (normalitas, heteroskedastisitas, multikolineritas, dan auto korelasi), analisis regresi linear berganda, uji $t$, uji f dan koefisien determinasi.

\section{HASIL PENELITIAN}

Hasil Analisis Statistik Deskriptif

Berdasarkan hasil analisis deskriptif, dapat diketahui dari 100 responden dalam penelitian ini mayoritas respondennya sebesar 94\% didominasi oleh responden yang berasal dari Provinsi Lampung, dan responden yang berasal dari Luar Provinsi Lampung sebanyak $4 \%$, lalu sebesar $91 \%$ didominasi oleh perempuan dan responden laki-laki sebanyak 6\%, dengan rentang usia terbesar 21-27 tahun (46\%). Berdasarkan pekerjaan, didominasi oleh pegawai negeri yakni dengan persentase $31 \%$, dengan pendapatan ratarata terbanyak dalam rentang Rp 2.000.000 - > Rp. 3.000 .000 per-bulan dengan presentase $72 \%$. 
Berdasarkan pengeluaran yang dilakukan di Butik Juragan Kain, 50\% responden mengeluarkan biaya dengan rentang Rp. 500.000- Rp. 600.000. Sebesar 57\% responden melakukan pembelian pada kunjungan pertama, dengan jumlah pembelian terbesar kurang dari sama dengan 2 kali (79\%). Berdasarkan pengetahuan tentang trend fashion, sebanyak $89 \%$ mengetahui tentang trend fashion, dan sebesar $49 \%$ responden mengetahui jenis trend ethnic fashion. Dalam mengetahui trend fashion, responden mendapatkan informasi melalui rekomendasi seseorang sebesar $73 \%$ dengan intensitas pertemuan sebanyak kurang dari sama dengan 2 kali per minggu sebesar $89 \%$.

\section{Distribusi Jawaban Responden}

Pengalaman pelanggan menjadi salah satu variabel penting yang dapat memengaruhi keputusan pembelian seseorang. Penilaian tertinggi terletak pada indikator sense dan feel dari interpretasi skala jawaban responden terhadap variabel pengalaman pelanggan (X1), memiliki nilai rata-rata sebesar 4.18. Sedangkan item yang berada dibawah rata-rata terletak pada indikator relate sebesar 3.6.

Pada variabel reference group (X2), memiliki nilai interpretasi nilai rata-rata tertinggi sebesar 3.7 meliputi saran dari sahabat, review pengalaman belanja dan rekan kerja. Sedangkan item yang dibawah rata-rata, meliputi saran dari orang tua dan dukungan dari suatu komunitas organisasi sebesar 3.27.

Pada variabel persepsi harga (X3), nilai rata-rata tertinggi sebesar 3.94, meliputi kesesuaian harga dengan kualitas produk, dan kesesuaian harga dengan manfaat produk sebesar 4.05. Sedangkan item terendah yaitu keterjangkauan harga, sebesar 3.76. Sementara itu, pada variabel keputusan pembelian (Y), nilai rata-rata tertinggi sebesar 4.12, meliputi kaidah konjungtif (keputusan pembelian dikarenakan pengalaman yang dirasakan baik, keputusan pembelian dikarenakan rekomendasi dari teman sekelompok), kaidah disjungtif (keputusan pembelian setelah membandingkan dengan toko lain, dikarenakan bahan dari produk halus dan pelayanan yang diberikan baik) dan kaidah leksikografis (keputusan pembelian dikarenakan pelayanan yang diberikan baik). Sedangkan item yang berada dibawah rata-rata meliputi kaidah konjungtif (keputusan pembelian dikarenakan harga yang terjangkau) sebesar 3.81, kaidah leksikografis (keputusan pembelian karena bahannya baik dan keputusan pembelian dikarenakan desain yang unik) sebesar 4.11 dan 4.05.

\section{Uji Asumsi Klasik}

Uji Normalitas

Uji Normalitas dapat dilakukan dengan melihat penyebaran data atau titik pada sumbu diagonal dari grafik atau dengan melihat histogram dari residualnya. Uji ini bertujuan untuk menguji apakah dalam sebuah model regresi, variabel independen, variabel dependen atau keduanya memiliki distribusi normal atau tidak. Selain itu, pengujian normalitas data bertujuan untuk mengetahui apakah distribusi data yang didapatkan dari penyebaran kuesioner kepada para responden penelitian yang terdiri dari beberapa unsur yang mewakili beberapa pihak berdistribusi normal atau tidak. Persamaan regresi dikatakan baik jika memiliki data yang terdistribusi mendekati normal atau mengikuti arah garis diagonal 


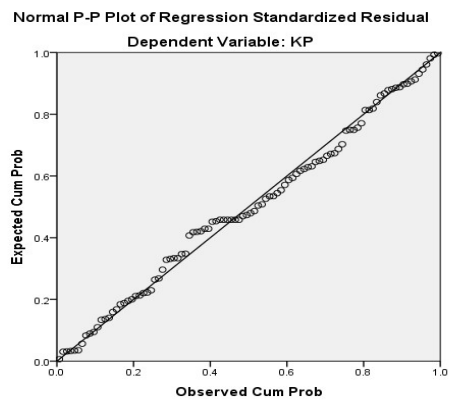

Gambar 2. Hasil Uji Normalitas Data

Berdasarkan Normal P-Plot Regression Standarized Residual pada Gambar 2 diketahui bahwa dalam penelitian ini, menunjukkan variabel yang diuji berdistribusi normal, karena garis titik-titik mengikuti garis diagonal. Hal ini juga menunjukkan bahwa penyebaran kuesioner penelitian ini telah terdistribusi normal dan mewakili beberapa pihak (subpopulasi). Dengan demikian, residual dalam penelitian ini telah memenuhi asumsi normalitas.

\section{Uji Heteroskedastisitas}

Uji Heteroskesdastisitas memiliki tujuan untuk menguji apakah dalam model regresi terdapat ketidaksamaan varian dari residual satu pengamatan ke pengamatan yang lainnya (Ghozali, 2018:137). Jika varian dari residual satu pengamatan ke pengamatan lain tetap, maka disebut homokesdastitas. Model regresi yang baik adalah yang homokesdastisitas atau yang tidak terjadi heteroskesdastisitas. Uji heteroskesdastisitas dilakukan dengan melihat grafik plot antara nilai prediksi variabel terikat yaitu ZPRED dengan residualnya SRESID. Deteksi ada tidaknya heteroskesdastisitas dapat dilakukan dengan melihat ada tidaknya pola tertentu pada grafik scatterplot. Hasil uji heteroskesdastisitas dalam penelitian ini dapat dilihat pada gambar berikut:

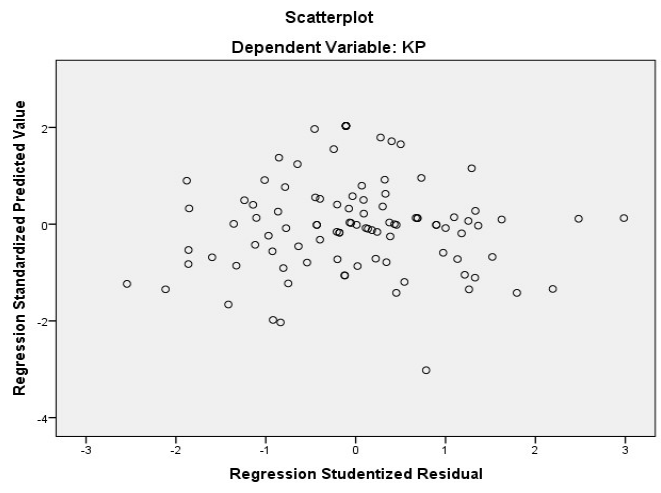

Gambar 3. Hasil Uji Heteroskedastisitas

Berdasarkan gambar 3 terlihat bahwa pola pada penyebaran data berupa titik-titik pada scatterplot tidak membentuk suatu pola atur alur tertentu, sehinga dapat disimpulkan bahwa tidak terjadi heteroskedastisitas. Dengan demikian uji klasik heteroskedastisitas dalam model ini terpenuhi. Uji ini dilakukan untuk mengetahui adanya penyimpangan dari syarat-syarat asumsi klasik pada regresi linear berganda dimana dalam model regresi harus dipenuhi syarat tidak adanya heteroskedastisitas. 


\section{Uji Multikolinieritas}

Uji multikolinearitas berfungsi untuk menguji apakah model regresi ditemukan adanya korelasi antar variabel independen atau variabel $x$. Model regresi yang baik ialah yang tidak terjadi korelasi diantara variabel independen. Untuk melihat apakah ada multikolinieritas pada hasil penelitian, maka dapat dilihat dari nilai Variance Inflation Factor (VIF) dan Tolerance. Jika nilai tolerance $>0,10$ dan nilai VIF $<10$, maka variabel tersebut tidak mempunyai persoalan multikolinieritas dengan variabel bebas lainnya. Adapun tabel untuk melihat hasil uji multikolinieritas dapat dilihat pada tabel berikut:

\begin{tabular}{|c|c|c|c|c|c|c|c|}
\hline \multirow[b]{2}{*}{ Model } & \multicolumn{2}{|c|}{$\begin{array}{l}\text { Unstandardized } \\
\text { Coefficients }\end{array}$} & \multirow{2}{*}{\begin{tabular}{|l|} 
Standardized \\
Coefficients \\
Beta \\
\end{tabular}} & \multirow[b]{2}{*}{$\mathrm{T}$} & \multirow[b]{2}{*}{ Sig. } & \multicolumn{2}{|c|}{ Collinearity Statistics } \\
\hline & B & Std. Error & & & & Tolerance & VIF \\
\hline (Constant) & 4.197 & 2.015 & & 2.082 & .040 & & \\
\hline PP & .230 & .056 & .345 & 4.115 & .000 & .421 & 2.377 \\
\hline RG & .284 & .096 & .228 & 2.948 & .004 & .497 & 2.013 \\
\hline $\mathrm{PH}$ & .560 & .115 & .383 & 4.860 & .000 & .477 & 2.097 \\
\hline
\end{tabular}

Tabel 1. Hasil Uji Multikoloneritas

a. Dependent Variable: KP

Pada hasil uji multikolinieritas menunjukan bahwa keseluruhan variabel bebas memiliki nilai Variances Inflanction Faktor (VIF) $<10$ dan nilai tolerance $>0,10$. Maka dapat disimpulkan dalam penelitian ini tidak terjadi multikolinieritas yang berarti tidak terdapat korelasi antar variabel bebas atau variabel independen sehingga tidak mengganggu hubungan antar varaibel bebas dan terikat.

\section{Analisis Regresi Linear Berganda}

Analisis regresi linear berganda digunakan dalam penelitian ini untuk menggambarkan ada atau tidaknya pengaruh antar variabel dengan suatu variabel dependen. Variabel independen atau bebas dalam penelitian ini adalah pengalaman pelanggan (X1), reference group $(\mathrm{X} 2)$, persepsi harga $(\mathrm{X} 3)$, sedangkan variabel dependen atau terikat pada penelitian ini adalah keputusan pembelian (Y) produk ethnic fashion di Butik Juragan Kain. Perhitungan statistik dalam analisis regresi linear berganda yang digunakan dalam penelitian ini adalah dengan menggunakan program SPSS 23.0. Hasil dari analisis regresi linear berganda dapat dilihat pada tabel berikut:

Tabel 2. Hasil Analisis Regresi Linear Berganda

\begin{tabular}{|c|c|c|c|c|c|c|}
\hline \multicolumn{7}{|c|}{ Coefficients $^{a}$} \\
\hline \multirow{2}{*}{ Model } & & \multicolumn{2}{|c|}{$\begin{array}{l}\text { Unstandardized } \\
\text { Coefficients }\end{array}$} & \multirow{2}{*}{\begin{tabular}{|l|} 
Standardized \\
Coefficients \\
Beta
\end{tabular}} & \multirow[b]{2}{*}{$t$} & \multirow[b]{2}{*}{ Sig. } \\
\hline & & $B$ & Std. Error & & & \\
\hline 1 & (Constant) & 4.197 & 2.015 & & 2.082 & .040 \\
\hline & $\begin{array}{l}\text { Pengalaman } \\
\text { Pelanggan }\end{array}$ & 230 & .056 & 345 & 4.115 & .000 \\
\hline & Reference Group & .284 & .096 & 228 & 2.948 & .004 \\
\hline 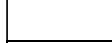 & Persepsi Harga & .560 & .115 & .383 & 4.860 & .000 \\
\hline
\end{tabular}


Berdasarkan tabel 2, hasil perhitungan regresi linear berganda, dapat diketahui bahwa nilai constant sebesar 4,197 nilai pengalaman pelanggan (X1) sebesar 0,230, nilai reference group (X2) sebesar 0,284, serta nilai persepsi harga (X3) sebesar 0,560. Berdasarkan nilai-nilai tersebut pada masing-masing variabel, maka untuk mengetahui pengalaman pelanggan, reference group, persepsi harga, terhadap keputusan pembelian konsumen pada produk Butik Juragan kain dapat dilihat pada persamaan regresi berikut:

$\mathrm{Y}=4,197+0,230+0,284+0,560+\mathrm{e}$

$$
Y=\alpha+\beta_{1} X 1+\beta_{2} X 2+\beta_{3} X 3+e
$$

Keterangan:

Y : Keputusan Pembelian

a : Konstanta

$\beta$ : Koefesien Regresi

X1 : Pengalaman Pelanggan

X2 : Reference Group

X3 : Persepsi Harga

$e$ : epsilon (faktor lain yang tidak diteliti)

Persamaan regresi dalam penelitian ini memiliki konstanta sebesar 4,197 yang berarti bahwa jika variabel independen pengalaman pelanggan $(\mathrm{X} 1)$, reference group $(\mathrm{X} 2)$, persepsi harga (X3), memiliki nilai 0, maka nilai variabel dependen keputusan pembelian (Y) adalah sebesar 4,197 Koefisien regresi linear berganda variabel pengalaman pelanggan (X1), bernilai positif sebesar 0,230 . Hal ini menunjukkan bahwa terjadi pengaruh yang positif antara variabel pengalaman pelanggan (X1), (variabel independen) terhadap keputusan pembelian (variabel dependen). Artinya setiap terjadi kenaikan nilai 1 dari variabel pengalaman pelanggan,, maka keputusan pembelian konsumen pada produk Butik Juragan kain akan mengalami peningkatan sebesar 0,230.

Koefisien regresi linear berganda variabel reference group (X2) bernilai positif sebesar 0,284 . Hal ini menunjukkan bahwa terjadi pengaruh yang positif antara variabel reference group (variabel independen) terhadap keputusan pembelian (variabel dependen). Artinya setiap terjadi kenaikan nilai 1 dari variabel reference group, maka keputusan pembelian konsumen pada produk Butik Juragan kain akan mengalami peningkatan sebesar 0,284. Koefisien regresi linear berganda variabel persepsi harga (X3) bernilai positif sebesar 0,560. Hal ini menunjukkan bahwa terjadi pengaruh yang positif antara variabel persepsi harga (variabel independen) terhadap keputusan pembelian (variabel dependen). Artinya setiap terjadi kenaikan nilai 1 dari variabel gaya hidup, maka keputusan pembelian konsumen pada produk Butik Juragan kain akan mengalami peningkatan sebesar 0,546.

\section{Uji Hipotesis}

Pengujian hipotesis dalam penelitian ini menggunakan pengujian secara parsial yang terdiri dari uji $t$, pengujian secara simultan yakni dengan uji F. berikut merupakan hasil uji hipotesis menggunakan aplikasi SPSS 23.0.

Berdasarkan tabel 3, dapat dilihat bahwa Hasil uji X1 terhadap Y Pada variabel pengalaman pelanggan (X1) memiliki nilai t-hitung sebesar 4,115, dan t-tabel sebesar 1,660, yang berarti t-hitung $>$ t-tabel. Variabel pengalaman pelanggan memiliki nilai signifikansi sebesar 0,000 atau memiliki nilai < 0,05. Hal tersebut dapat diartikan bahwa secara parsial 
variabel pengalaman pelanggan memiliki pengaruh yang signifikan terhadap keputusan pembelian produk Butik Juragan Kain. Maka dapat disimpulkan bahwa H1 diterima.

Tabel 3. Hasil uji t

\begin{tabular}{|l|l|l|l|l|l|}
\hline \multirow{2}{*}{ Variabel } & \multicolumn{2}{|l|}{$\begin{array}{l}\text { Standardized } \\
\text { Coefficients }\end{array}$} & \multicolumn{4}{|l|}{} \\
\cline { 2 - 6 } & Beta & \multicolumn{1}{|l|}{$\mathbf{t}_{\text {hitung }}$} & $\mathbf{t}_{\text {tabel }}$ & Sig & Keterangan \\
\cline { 2 - 6 } & & 2,082 & & 0,040 & \\
\hline $\begin{array}{l}\text { Pengalaman } \\
\text { Pelanggan } \\
\rightarrow \mathrm{Y})\end{array}$ & 0.345 & 4,115 & 1,660 & 0,000 & $\begin{array}{l}\text { Ha diterima, Ho } \\
\text { ditolak }\end{array}$ \\
\hline $\begin{array}{l}\text { Reference Group } \\
(\mathrm{X} 2 \rightarrow \mathrm{Y})\end{array}$ & 0.228 & 2,948 & 1,660 & 0,004 & $\begin{array}{l}\text { Ha diterima, Ho } \\
\text { ditolak }\end{array}$ \\
\hline $\begin{array}{l}\text { Persepsi Harga } \\
(\mathrm{X} 3 \rightarrow \mathrm{Y})\end{array}$ & 0.383 & 4,860 & 1,660 & 0,000 & $\begin{array}{l}\text { Ha diterima, Ho } \\
\text { ditolak }\end{array}$ \\
\hline
\end{tabular}

Hasil uji X2 terhadap Y Pada variabel reference group (X2) memiliki nilai t-hitung sebesar 2,948, dan t-tabel sebesar 1,660, yang berarti t-hitung $>$ t-tabel. Kemudian, variabel kelompok referensi memiliki nilai signifikansi sebesar 0,004 atau memiliki nilai < 0,05. Hal tersebut dapat diartikan bahwa secara parsial variabel reference group memiliki pengaruh yang signifikan terhadap keputusan pembelian produk Butik Juragan Kain.. Maka dapat disimpulkan bahwa $\mathrm{H} 2$ diterima.

Hasil uji X3 terhadap Y Pada variabel persepsi harga (X3) memiliki nilai t-hitung sebesar 4,860, dan t-tabel sebesar 1,660, yang berarti t-hitung $>\mathrm{t}$-tabel. Variabel gaya hidup memiliki nilai signifikansi sebesar 0,000 atau memiliki nilai $<0,05$. Hal tersebut dapat diartikan bahwa secara parsial variabel persepsi harga memiliki pengaruh yang signifikan terhadap keputusan pembelian produk Butik Juragan Kain. Maka dapat disimpulkan bahwa H3 diterima.

Tabel 4. Hasil uji F

\begin{tabular}{|c|c|c|c|c|c|c|}
\hline \multicolumn{7}{|c|}{ ANOVA $^{a}$} \\
\hline \multicolumn{2}{|c|}{ Model } & $\begin{array}{l}\text { Sum } \\
\text { Squares }\end{array}$ & Df & Mean S & $\mathrm{F}$ & \multirow{2}{*}{$\frac{\text { Sig. }}{.000^{\mathrm{b}}}$} \\
\hline \multirow[t]{3}{*}{1} & Regression & 1245.934 & 3 & 415.311 & 80.549 & \\
\hline & Residual & 494.976 & 96 & 5.156 & & \\
\hline & Total & 1740.910 & 99 & & & \\
\hline \multicolumn{7}{|c|}{ a. Dependent Variable: KP } \\
\hline \multicolumn{7}{|c|}{ b. Predictors: (Constant), PH, RG, PP } \\
\hline
\end{tabular}

Berdasarkan tabel 4, dapat dilihat nilai F hitung $(80,549)>\mathrm{F}$ tabel $(2,70)$, dengan nilai Sig. $<0,05$, sehingga dapat disimpulkan bahwa terdapat pengaruh secara simultan antara pengalaman pelanggan, reference group dan persepsi harga terhadap keputusan pembelian. Maka dari itu dapat disimpulkan bahwa H4 diterima.

\section{Koefisien Determinasi}

Berdarkan tabel 5, didapat nilai $R$ square sebesar 0,716, sehingga dapat disimpulkan variabel bebas yang digunakan pada penelitian kali ini dapat mempengaruhi variabel 
dependen sebesar 71,6\%, dan 28,4\% lainnya dipengaruhi oleh variabel lainnya yang tidak diteliti dalam penelitian ini.

Tabel 5. Hasil Koefisien Determinasi (Uji R²)

\begin{tabular}{|l|l|l|l|l|}
\hline \multicolumn{5}{|l|}{ Model Summary } \\
\hline Model & $R$ & $R$ Square & $\begin{array}{l}\text { Adjusted } \\
\text { Square }\end{array}$ & $\begin{array}{l}\text { R Std. Error of } \\
\text { the Estimate }\end{array}$ \\
\hline 1 & $.846^{\mathrm{a}}$ & .716 & .707 & 2.27068 \\
\hline a. Predictors: (Constant), PH, RG, PP \\
b. Dependent Variable: KP \\
b. \\
\hline
\end{tabular}

\section{PEMBAHASAN}

Pengaruh Pengalaman Pelanggan Terhadap Keputusan Pembelian

Hasil pengujian mengindikasi bahwa pengalaman pelanggan memiliki pengaruh positif dan signifikan terhadap keputusan pembelian produk ethnic fashion. Variabel pengalaman pelanggan berpengaruh terhadap keputusan pembelian sebesar 34,5\%. Hal ini didukung dengan hasil analisis deskriptif dimana responden memberikan penilaian tertinggi pada indikator sense (dilihat dari kemasan) dan feel (dilihat dari pelayanan). Responden tidak hanya mementingkan kualitas dari suatu produk, tetapi responden juga menilai packaging (kemasan) dari suatu produk. Kemasan yang terlihat elegan, membuat konsumen merasa produk yang dibeli merupakan produk yang istimewa, berkualitas, dan mahal. Sehingga, aspek kemasan produk juga menjadi satu hal yang mempengaruhi sikap pembelian mereka.

Selain itu, responden merasa pelayanan yang diberikan Butik Juragan Kain sangat baik, karyawan dari Juragan kain melayani pertanyaan konsumen dengan sangat ramah sehingga membuat konsumen pun tidak segan untuk bertanya, karyawan maupun pemilik Butik Juragan Kain tidak segan untuk membantu konsumen dalam mencoba pakaian yang akan mereka beli.

Hasil penelitian ini sejalan dengan penelitian yang dilakukan (Sandi, 2017) yang menemukan adanya pengaruh positif dan signifikan pada variabel pengalaman pelanggan terhadap keputusan pembelian.

\section{Pengaruh Reference Group Terhadap Keputusan Pembelian}

Hasil pengujian mengindikasi bahwa reference group memiliki pengaruh positif dan signifikan terhadap keputusan pembelian produk ethnic fashion. Variabel reference group berpengaruh terhadap keputusan pembelian sebesar 22,8\%. Hal ini didukung dengan hasil analisis deskriptif dimana responden memberikan penilaian tertinggi pada indikator kelompok rekan kerja. Responden merasa pengaruh yang di didapatkan dari rekan kerja sangat kuat dalam menentukan keputusan pembelian pada Butik Juragan Kain, sesuai dengan data karaktersitik responden dimana mayoritas yang membeli produk Juragan Kain adalah pegawai negeri dan pegawai swasta (sudah bekerja).

Hasil penelitian ini juga searah dengan penelitian yang dilakukan oleh Pramudi (2015) yang menyatakan bahwa kelompok referensi memegang peranan penting. Kelompok referensi berpengaruh terhadap keputusan pembelian sehingga jika kelompok referensi memberikan saran yang lebih, maka konsumen berpeluang besar dalam membeli suatu 
produk.

Pengaruh Persepsi Harga Terhadap Keputusan Pembelian

Hasil pengujian mengindikasi bahwa persepsi harga memiliki pengaruh positif dan signifikan terhadap keputusan pembelian produk ethnic fashion. Variabel persepsi harga berpengaruh terhadap keputusan pembelian sebesar 38,3\%. Hal ini didukung dengan hasil analisis deskriptif dimana responden memberikan penilaian tertinggi pada indikator kesesuaian harga dengan kualitas produk. Responden merasa bahwa harga produk Butik Juragan Kain sudah sesuai dengan kualitas dari produk yang diberikan. Konsumen tidak mempermasalahkan tinggi atau rendahnya suatu harga, jika dirasa harga sudah sesuai dengan kualitas yang diberikan.

Hasil penelitian ini sejalan dengan penelitian yang pernah dilakukan Jamaludin et al (2015), bahwa terdapat pengaruh positif persepsi harga terhadap keputusan pembelian. Hal tersebut menjadi strategi yang dilakukan Butik Juragan Kain dalam memasarkan produknya, yaitu dengan penentuan harga yang tepat, sejalan dengan kualitas yang akan diberikan. Sebagian besar produk etnik memiliki harga yang tinggi karena handmade dan membutuhkan perlakuan ekstra agar tidak merusak kualitas produk.

Konsumen yang membeli produk di Juragan Kain, mendapatkan produk yang sudah di-dry cleaning terlebih dahulu, dikemas dengan hanger dan plastik pelindung pakaian, serta paper bag yang elegan. Sehingga, walaupun harga produk tergolong tinggi, konsumen merasa mendapatkan produk yang berkualitas, terawat dengan baik, dikemas dengan menarik, dan sudah mendapatkan ekstra pencucian produk yang tidak merusak kualitas kain.

Pengaruh Pengalaman Pelanggan, Reference Group, dan Persepsi Harga terhadap Keputusan Pembelian

Secara keseluruhan, hasil pengujian hipotesis juga menunjukkan terdapat pengaruh secara simultan pengalaman pelanggan, reference group, dan persepsi harga terhadap keputusan pembelian produk ethnic fashion Butik Juragan Kain. Variabel persepsi harga pada penelitian ini memiliki pengaruh yang paling tinggi, diikuti dengan variabel pengalaman pelanggan yang berpengaruh lebih dibanding variabel reference group terhadap keputusan pembelian produk ethnic fashion Butik Juragan Kain.

Penelitian ini sejalan dengan penelitian terdahulu yang menyatakan bahwa pengalaman pelanggan, reference group, dan persepsi harga memiliki pengaruh yang signifikan terhadap keputusan pembelian (Sidabutar et al., 2016:96; Apriyandani et al., 2017:187; Jamaludin et al., 2015:6). Hasil tersebut juga diperkuat oleh análisis deskriptif dimana responden memberikan penilaian di atas rata-rata pada variabel pengalaman pelanggan yakni pada ítem "kemasan yang terlihat elegan" dan "pelayanan yang diberikan responsif", lalu pada variabel reference group pada ítem "kelompok rekan kerja" dan pada persepsi harga yakni pada ítem "kesesuaian harga dengan kualitas produk".

Hasil penelitian ini menunjukkan bahwa pengaruh persepsi harga lebih besar (38,3\%) daripada pengalaman pelanggan $(34,5 \%)$, dan reference group $(22,8 \%)$ terhadap terbentuknya keputusan pembelian produk ethnic fashion. Hasil tersebut juga diperkuat oleh analisis deskriptif dimana responden memberikan penilaian di atas rata-rata pada indikator "kesesuaian harga dengan kualitas produk". Hal ini menjelaskan bahwa pada industri fashion, persepsi harga menjadi faktor utama yang mendukung keputusan akhir saat 
memutuskan pembelian. Sejalan dengan hasil penelitian yang dilakukan oleh Jamaludin et al (2015:6), bahwa variabel persepsi harga memiliki pengaruh terbesar terhadap keputusan pembelian. Berdasarkan hal tersebut, responden merasa kualitas yang diberikan sesuai dengan harga yang ditawarkan, disertai dengan pelayanan yang baik dan responsif yang membuat pelanggan merasa diistimewakan.

Walaupun demikian, pada penelitian ini, item "keterjangkauan harga" memiliki nilai terendah. Maka dari itu, pihak Butik Juragan Kain diharapkan dapat menghadirkan ragam produk dengan kualitas yang berbeda dan lebih terjangkau, atau mengadakan sale session pada waktu tertentu.

\section{KESIMPULAN}

Berdasarkan hasil penelitian, terdapat pengaruh secara parsial dan simultan antara variabel pengalaman pelanggan, reference group dan persepsi harga terhadap keputusan pembelian produk ethnic fashion pada konsumen Butik Juragan Kain. Pengaruh terbesar terletak pada variabel persepsi harga. Dengan demikian, pihak Butik Juragan Kain dapat dapat mempertahankan aspek-aspek yang mendukung menjamin kualitas produk yang diberikan dalam memenuhi kebutuhan dan keinginan konsumen, mempertahankan konsistensi kualitas produk yang sesuai dengan harga produk yang ditetapkan, memberikan pelayanan tambahan agar konsumen merasa diperlakukan istimewa, dan juga membentuk pengalaman pelanggan yang menyenangkan. Selain itu, untuk menyasar segementasi anak muda, pihak Butik Juragan Kain dapat menghadirkan ragam produk dengan kualitas yang berbeda dan lebih terjangkau atau mengadakan sale session pada waktu tertentu. Pengembangan penelitian lebih lanjut perlu dilakukan dengan mempertimbangkan penambahan variabel kualitas produk. Karena pada penelitian ini, kesesuaian harga dengan kualitas produk merupakan item dalam indikator persepsi harga, memiliki penilaian tertinggi dari responden. Perlu juga dilakukan penelitian lebih lanjut untuk dapat mengukur dan mengembangkan variabel kualitas produk.

\section{DAFTAR PUSTAKA}

Apriyandani, H., Yulianto, E., \& Sunarti. (2017). Pengaruh gaya hidup dan kelompok referensi terhadap keputusan pembeliann (Survei mahasiswa S1 fakultas ilmu administrasi angkatan 2014 dan 2015 Universitas Brawijaya Malang yang membeli dan menggunakan smartphone iPhone). Jurnal Administrasi Bisnis (JAB), 50(2), 180-189.

Ghozali, I. (2011). Aplikasi analisis multivariate dengan program SPSS. Badan Penerbit Universitas Diponegoro: Semarang.

Hawkin, D. \& Mothersbaugh, D. (2010). Consumen behaviour: Building makrketing strategy, 11' Edition. Mc Graw- Hill: Irwin.

Jamaludin, A., Arifin, Z., \& Hidayat, K. (2015). Pengaruh promosi online dan persepsi harga terhadap keputusan pembelian (Survei pada pelanggan Aryka Shop di Kota Malang). Jurnal Administrasi Bisnis (JAB), 21(1), 1-8.

Schmitt, B. H. (1999). Experiential marketing: How to get costumer to sense, feel, think, act, and relate to your company and brands. New York: The Free Press.

Schiffman \& Kanuk. (2008). Perilaku konsumen, Edisi 7. PT. Indeks: Jakarta.

Sidabutar, C., Suharyono, \& Kusumawati, A. (2016). Pengaruh experiental marketing dan emosional marketing terhadap keputusan pembelian (Survei konsumen sepatu Nike di Indonesia dan di Malaysia). Jurnal Administrasi Bisnis (JAB), 39(2), 92-99. 
Sugiyono. (2017). Metode penelitian bisnis: Pendekatan kuantitatif, kualitatif, kombinasi, dan RED. Alfabeta: Bandung.

Tjiptono, F. (2010). Strategi pemasaran, Edisi 2. Andi Offset: Yogyakarta. 